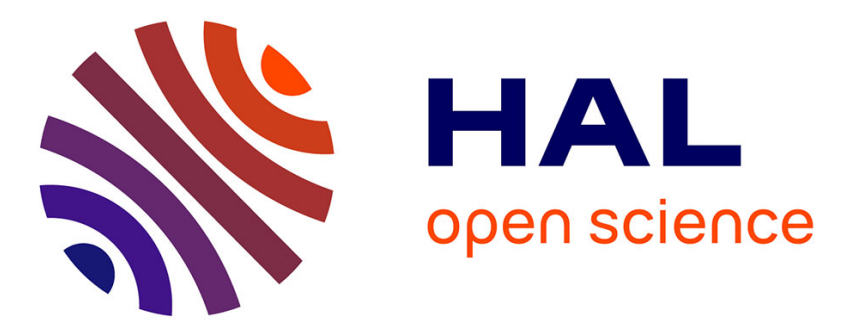

\title{
Response of surface energy balance to water regime and vegetation development in a Sahelian landscape
}

Franck Timouk, L. Kergoat, Éric Mougin, C. R. Lloyd, Eric Ceschia, J.M.

Cohard, Patricia de Rosnay, Pierre Hiernaux, Valérie Demarez, C.M. Taylor

\section{- To cite this version:}

Franck Timouk, L. Kergoat, Éric Mougin, C. R. Lloyd, Eric Ceschia, et al.. Response of surface energy balance to water regime and vegetation development in a Sahelian landscape. Journal of Hydrology, 2009, pp.1-43. 10.1016/j.jhydrol.2009.04.022 . ird-00392519

\section{HAL Id: ird-00392519 \\ https://hal.ird.fr/ird-00392519}

Submitted on 8 Jun 2009

HAL is a multi-disciplinary open access archive for the deposit and dissemination of scientific research documents, whether they are published or not. The documents may come from teaching and research institutions in France or abroad, or from public or private research centers.
L'archive ouverte pluridisciplinaire HAL, est destinée au dépôt et à la diffusion de documents scientifiques de niveau recherche, publiés ou non, émanant des établissements d'enseignement et de recherche français ou étrangers, des laboratoires publics ou privés. 


\section{Sahelian landscape.}

3

4 Timouk F. ${ }^{1}$, Kergoat L. ${ }^{1}$, Mougin E. ${ }^{1}$, Lloyd C.R. ${ }^{2}$, Ceschia E. ${ }^{1}$, Cohard J.-M. ${ }^{3}$, de Rosnay P. ${ }^{1}$, 5

$$
\text { Hiernaux P. }{ }^{1} \text {, Demarez V. }{ }^{1} \text {, Taylor C.M. }{ }^{2}
$$

6

7

${ }^{1}$ CESBIO (CNRS/UPS/IRD/CNES), Toulouse,France

8

${ }^{2}$ CEH, Wallingford, UK

9

${ }^{3}$ LTHE (UJF), Grenoble, France

10

11

12

13

14

15

16

17

18

19

20

21

22

23

24

25 
3 The West African monsoon interacts strongly with the land surface, yet knowledge of these

4 interactions is severely limited by the lack of observations of surface energy fluxes. Within

5 the framework of the AMMA project, three eddy covariance flux stations were installed to 6 sample the three main surface types near Hombori (Mali) in the central Sahel at $15.3^{\circ} \mathrm{N}$, and a

7 fourth station was installed near Bamba in the northern Sahel at $17.1^{\circ} \mathrm{N}$ to sample semi-desert conditions. Observed land types near Hombori comprised a grassland growing on sandy soil

9 (near the village of Agoufou), a flooded forest in a clay-soil depression (Kelma), and a bare rocky soil (Eguerit). The energy balance closure at the grassland site was satisfactory, but less so at the flooded forest site. Surface water heat storage during the flood and advection probably were responsible for most of the imbalance.

The daily sensible heat flux $(H)$ was fairly constant throughout the year at Bamba and Eguerit,

with only a slight increase during the monsoon season corresponding to increased net radiation. By contrast, the seasonal cycle of the grassland site was marked, with $H$ decreasing during the monsoon season from $70 \mathrm{Wm}^{-2}$ in May to $20 \mathrm{Wm}^{-2}$ in August. The flooded woodland exhibited the strongest contrast between the dry and wet seasons, with daily sensible heat flux close to zero during the flood. During the peak monsoon season, the two vegetated sites had the highest net radiation and the lowest sensible heat flux, as a consequence of the strong evapotranspiration rates caused by both high soil moisture availability and high Leaf Area Index. Lateral fluxes of water were found to be strong drivers of inter-site sensible and latent heat fluxes variability, with water leaving bare rocky soils as surface runoff and ending in the clay depressions (e.g., Kelma), whereas the sandy soils were locally endorheic, with most of the rainfall being rapidly returned to the atmosphere. 
1 An attempt was made to scale the sensible heat flux up to the scale of the AMMA northern

2 supersite (60 km by $60 \mathrm{~km}$ ), following a simple scaling scheme, which accounted for the

3 contrasting surface types and water regimes. The super-site average sensible heat flux proved

4 to be close to the grassland sensible heat flux, in part because grassland occupies $55 \%$ of the

5 area. A strong spatial variability was caused by the difference in water regime and vegetation

6 type, at a scale large enough to potentially influence the atmospheric properties such as the 7 boundary layer.

8 Keywords : Sahel - sensible heat flux - latent heat flux - net radiation - grassland - bare soil 9 - flooded forest - AMMA

\section{Introduction}

The West African monsoon (WAM) has been shown to depend significantly on surfaceatmosphere interaction, at the large scale (Charney et al. 1975, Nicholson et al. 1998, Zeng et al. 1999, Nicholson 2000) as well as at the meso-scale (Clark et al. 2004, Taylor et al. 2007, Mohr et al. 2003). The land surface is currently thought to act as a strong amplifier of the WAM inter-annual variability, which is at least partially triggered by ocean SST anomalies (Gianini et al. 2003). As a result, the whole water cycle of the monsoon is affected by the land surface energy and mass fluxes. There is a need to understand and quantify the processes, which control the surface fluxes in West-Africa, as well as to evaluate land surface models (de Rosnay et al. 2006). Evaluation can be performed at the local scale, using flux time series where they exist (FLUXNET, Baldocchi et al. 2001), but it becomes increasingly important to assess the surface fluxes at the landscape scale. Both the average value, which corresponds to the grid cell of large scale models, and the spatial variability of the fluxes are of interest (e.g. LeMone et al. 2007). The land surface is characterized by a significant heterogeneity created 
1 by topography, soil type, land use, and land cover. In addition, the surface fluxes are

2 modulated by atmospheric forcings, with precipitation being of utmost importance in semi-

3 arid regions. It has been shown that mesoscale heterogeneity greatly influences the

4 atmospheric boundary layer and thermodynamics, mesoscale circulations, and convection

5 triggering and intensity (LeMone et al. 2007 and references therein, Clark et al. 2004).

6 Modelling studies have suggested that surface heterogeneity potentially has an effect on

7 rainfall in the tropics (Avissar et al. 2004).

8 Unfortunately, the current understanding of the surface / atmosphere interactions is severely

9 limited by a lack of observations, West-Africa being one of the less instrumented regions of the world. The AMMA/Catch (African Monsoon Multidisciplinary Analyses / Couplage de

11 l'Atmosphère Tropicale et du Cycle Hydrologique) network provides datasets, which can be 12 used to scrutinize land surface fluxes with unprecedented focus and accuracy. For instance, the development of a network of flux measurement stations provides the opportunity to explore the time and space variability of these fluxes along a latitudinal transect, as well as the scaling of the fluxes from local to meso-scale. In this article, surface sensible heat fluxes measured at $15.3^{\circ} \mathrm{N}$ and $17^{\circ} \mathrm{N}$, over the northernmost AMMA/Catch meso-scale site, in the Malian Gourma, are presented. Instruments were deployed in the central and northern parts of the Sahel, for which no flux observations had been collected previously. The closest documented ecosystems are found in the southern Sahel, near Niamey (Niger), where the SEBEX and HAPEX-Sahel experiments took place, mostly during the 'dry-down' phase of the monsoon (Allen et al. 1994, Gash et al. 1997). The resulting data for millet crops, bush fallow and tiger bush proved critical in assessing model performance, (e.g. Taylor et al., 2002, Kahan et al., 2006). There is a need to carry out in-depth examination of land surface processes over different surface types in the central and northern Sahel regions. The seasonal 
1 types is described and the driving variables are identified. Since lateral water redistribution is

2 crucial to the soil moisture regime and vegetation development in this area, the roles of run-

3 off, run-on and locally endorheic systems on the sensible heat flux are investigated.

\section{Site description}

A comprehensive description of the northernmost AMMA/Catch site is provided by Mougin

et al., (this issue). Hiernaux et al. (this issue) describe the vegetation, Samain et al (2008),

Guichard et al., Frappart et al., (this issue) and de Rosnay et al. (this issue) document the meteorological, radiation and soil moisture networks. The climate is controlled by the monsoon, with south-westerly winds providing moist air from June to September, and northeasterly Harmattan winds bringing hot and dry air during the rest of the year. Rainfall averages $350 \mathrm{~mm}$ at Hombori and 150 at Bamba (semi-desert site of figure 1) and is brought by convective systems, mostly from early July to mid-September. The so-called Hombori super-site is a $60 \mathrm{~km}$ by $60 \mathrm{~km}$ area embedded in the larger meso-scale site, which extends from $14.5^{\circ} \mathrm{N}$ to $17.5^{\circ} \mathrm{N}$ (Fig. 1). Within the Hombori super-site, $55 \%$ of the area is covered by grasslands growing on sandy dunes (Fig. 2, grey), 35\% is bare soil (Fig. 2, white), comprising rocks topped with gravels (20\%), and loamy shallow soils (15\%), and 10\% consist of valleys and low-lands referred to as 'bas-fonds' in French, with clay soil (Fig. 2, black). Ponds and seasonally flooded woodlands are found in the lowest part of these depressions (5\%). Sandy dunes are locally endorheic (no runoff except over very short distance, of less than $100 \mathrm{~m}$ ), whereas bare soils generate substantial run-off into the depressions. Tree cover is low or non existent (of the order of 1\%) over bare soil. It is low over grasslands (generally between 0 end 5\%), but can reach 60\% in flooded Acacia stands in the clay soil depressions. 
Data

4 Four flux stations were operated in 2005, 2006 and 2007 to sample the three main surface 5 types as well as the latitudinal climate gradient $\left(15.3^{\circ} \mathrm{N}, 17.1^{\circ} \mathrm{N}\right)$. Three flux stations were 6 deployed within the super-site of $60 \mathrm{~km}$ by $60 \mathrm{~km}$ area, as shown in figures 1 and 2 . As such, 7 they broadly undergo the same climate conditions, apart from rainfall, which can differ, especially when short time scales are considered, such as the scale of an event or a convective cell within an event. In Eguerit, the flux station is installed on a bare, dark, hard pan outcrop. Net radiation has also been measured on nearby bright loamy bare soil during 56 days in 2008. The grassland (Agoufou) grows over bright sandy soil, dominated by annual grasses and forbs with $2 \%$ tree cover, mostly scattered Acacia, Combretum, Balanites and Leptadenia. Kelma is a seasonally flooded open woodland site, with a $40 \%$ tree cover (mostly from Acacia seyal and Acacia nilotica), growing on a loamy-clay soil. These sites are referred to as "bare rocky soil” (Eguerit), "grassland” (Agoufou) and "flooded forest” (Kelma). In addition to the 3 super-site stations, a fourth station was installed near Bamba at $17.1^{\circ} \mathrm{N}$ to sample semi-desert surface at the margins of the Sahara. This site belongs to a different ecoclimatic zone (Frappart et al., this issue) and is referred to as the "semi-desert site”. The soil is sandy and bright and vegetation is sparse at most, with a few scattered trees, perennial and short annual grasses. At the three supersite stations, grass Leaf Area Index (LAI) and tree Plant Area Index (PAI, including stems and branches) are monitored on a 10 day basis along a $221 \mathrm{~km}$ transect. The four components (incoming and outgoing short- and long-wave) of the radiation budget 24 were measured with a CNR1 (Kipp and Zonen, Delft, Holland) at the four sites and 25 calibration was checked in 2006. Additional radiation data were collected in September 2008 
1 to document bare soil albedo variability. Volumetric soil water content was monitored with

2 CS616 reflectometers (Campbell Scientific Inc., Logan, UT, USA), except in the loamy-clay

3 soil of Kelma, where ML2x theta probes (Delta T Devices Ltd, UK) were used. Gravimetric

4 measurements were performed at different stages of the rainy and dry seasons to ensure

5 calibration in various soil moisture conditions (see de Rosnay et al. this issue). Relative

6 humidity (\%) and air temperature $\left({ }^{\circ} \mathrm{C}\right)$ were also measured at $2.2 \mathrm{~m}$, and $7 \mathrm{~m}$ above ground in

7 the forest. HMP45C probes (Vaisala inc., Woburn, MA, USA) were used at the grassland and

8 semi-desert site, WXT510 (Vaisala inc., Woburn, MA, USA), weather transmitters were used

9 at the bare rocky soil and forest sites. All those parameters were measured every 10 seconds

10 and stored at a 30 min averaging interval.

11 Sensible heat flux was measured with sonic anemometers (Solent R3) measuring the three 12 vector components of the wind at $20 \mathrm{~Hz}$. Solent R3 (Gill Instruments, Lymington, UK) eddycovariance systems at the grassland and forest sites were replaced by Campbell CR3000CSAT3-LiCor7500 systems (Campbell Scientific Inc., Logan, UT, USA, Li-Cor Inc., Lincoln, NE, USA) in 2007, which allowed computation of latent heat fluxes. Soil heat flux was computed from soil temperature at two levels and compared with the flux measured by heat 17 flux plates at $5 \mathrm{~cm}$ in the soil.

Methods

The sensible heat, latent heat and CO2 fluxes were computed according to the eddy covariance methodology following the CarboEurope recommendations (Foken 2008, Mauder and Foken technical report, http://www.geo.uni-bayreuth.de/mikrometeorologie/ARBERG/ARBERG26.pdf) using standardised routines and the EdiRe software 
1 (http://www.geos.ed.ac.uk/abs/research/micromet/EdiRe).

2 The following processing steps were performed: detection and elimination of raw spikes, flux

3 loss corrections due to angle of attack applied to Solent R3 anemometers, 2D coordinate

4 rotation, conversion of buoyancy flux into heat flux (Schotanus et al. 1983) using relative

5 humidity when the molecular density of $\mathrm{H}_{2} \mathrm{O}$ was not available from Infra Red Gas Analysers,

6 spectral and stability corrections, and WPL calculations.

7 Ground heat fluxes were calculated by means of a Fourier decomposition of soil temperature 8 time series. It has been shown that this method provides ground heat fluxes which close the 9 surface energy balance with a good accuracy (Heusinkveld et al., 2004). The methodology is recalled in Guyot et al. (this issue). It consists of producing, day by day, Fourier series of the temperature at depth $z_{1}$. A daily thermal diffusion coefficient $D_{g}$ is calculated from the ratio of the amplitude of the temperature series at $z_{1}$ and $z_{2}$ (Verhoef et al. 1996). The diffusion heat equation for homogeneous ground is solved and provides the temperature $T(z, t)$ and its vertical gradient $\partial T / \partial z$ at any depth $z$ and any time $t$. The ground heat flux is obtained from eq. 1 where $\lambda_{\mathrm{g}}$ is the thermal conductivity of the ground. The latter is calculated from $\lambda_{\mathrm{g}}=D_{g} \cdot \rho_{g} \cdot C_{g}$ where $\rho_{g}$ is the density and $C_{g}$ the heat capacity of the ground. $\rho_{g} \cdot C_{g}$ is estimated from dry soil characteristics $\rho_{s} \cdot C_{s}$ with $\rho_{g} \cdot C_{g}=\rho_{s} \cdot C_{s}+\theta \cdot \rho_{w} \cdot C_{w}$, where $\theta$ is the volumetric soil humidity at $z_{1}$, and $\rho_{w}$ and $C_{w}$, are the density and heat capacity of water. A soil moisture dependence is then accounted for through these ground characteristics. Measured values for $\rho_{s}\left(1610 \mathrm{~kg} \cdot \mathrm{m}^{-3}\right)$ and a literature value for Cs (875 $\mathrm{Jkg}^{-1} \mathrm{~K}^{-1}$, Hillel 1998) have been used.

$$
\left.G\right|_{z=0}=-\lambda_{g} \partial T /\left.\partial z\right|_{z=0}
$$

The energy balance closure is examined by computing the imbalance according to equation 2 .

$$
E I=R_{N E T}-H-L E-G-S
$$


1 where $E I$ is for the energy imbalance and $S$ represents the storage terms. Over the last two

2 decades, persistent observations of imbalance ranging between 10 and $40 \%$ of the available

3 energy $R_{N E T}$ - $G$ led to the development of different correction terms in the calculation of the

4 turbulent fluxes, as mentioned above, and to the examination of all the so-called minor terms

5 (heat storage between the sonic and the ground, photosynthesis). Dedicated experiments have

6 been designed to address the energy balance closure problems (EBEX, Oncley et al. 2007).

7 Foken (2008) provides a synthesis of these findings. Here, we examine the energy balance

8 closure at three time scales. The sum of the turbulent fluxes $\mathrm{H}$ and LE plus the storage term S

9 is regressed against the available energy $R_{N E T}-G$ using all data at the 30 minutes time scale.

Day-time and 24h averages are also computed. The storage terms include the sensible heat stored in the air $\left(S_{a i r}\right)$ and the biomass $\left(S_{b i o}\right)$ between the sonic anemometer and the surface as well as the energy used in biochemical reactions $\left(S_{\text {pho }}\right)$, following Oncley et al. (2007).

$$
S_{\text {air }}=\rho \cdot C p \cdot Z \cdot\left(\Delta T_{\text {air }} / \Delta t\right)
$$

$$
S_{b i o}=C b \cdot B \cdot\left(\Delta \mathrm{T}_{a i r} / \Delta \mathrm{t}\right)
$$

$$
S_{p h o}=L p . F_{C O 2}
$$

16 where $\mathrm{Z}$ is the measurement height, $C_{b}$ is the heat capacity of woody biomass (3000 $\mathrm{Jkg}^{-1} \mathrm{~K}^{-1)}$, $17 B$ is the aboveground fresh biomass ( $4.5 \mathrm{kgm}^{-2}$ for the forest site), $L_{p}=482 \mathrm{Jmole}^{-1} \mathrm{CO}_{2}$ (Jacobs et al., 2008) and $F_{C O 2}$ is the net $\mathrm{CO}_{2}$ flux (mole s${ }^{-1} \mathrm{~m}^{-2}$ ).

19 Latent heat flux was estimated as the residual of the surface energy balance for the bare rocky soil (Eguerit) and semi-desert (Bamba) sites, in the absence of eddy covariance measurements of water vapour, using equation:

$$
L E=R_{N E T}-H-G-S
$$

Considering that the site is bare soil, the flux tower is low, and there is no photosynthesis flux, no storage terms were necessary for Eguerit and Bamba. The semi-desert site at $17^{\circ} .1 \mathrm{~N}$ 25 (Bamba) is prone to substantial sand deposition during dust storms, which produces 
1 significant accumulations over the soil temperature sensors, being as high as $50 \mathrm{~cm}$ per year.

2 The estimation of $L E$ as the residual of the energy balance at this site had therefore to rely on

3 the assumption that the soil heat flux is zero at the $24 \mathrm{~h}$ time scale.

5 Due to the harsh environment and the remoteness of the sites, instrument failures cause gaps 6 in the data. No gap filling was performed except for between day of year (DoY) 206 to DoY 7225 of 2007 to estimate accumulated evaporation for the grassland site, where a daily average evaporative fraction $L E$ / $R_{N E T}$ was computed using ten days before and after the gap. Long time series were obtained for 2005 and 2007 at the grassland site (with limited data in 2006) and for 2006 and 2007 at the forest site, whereas 2006 provided the longest record for the northern semi-desert site and 2005 for the bare rocky soil site.

12

In the following, data for different years are shown and pooled together to give a comprehensive view of all data collected over these sites during the AMMA Enhanced Observation Period (2005-2007).

\section{Results}

\section{Energy balance closure}

The energy balance closure provides a natural test to check the consistency of eddy covariance flux data. Indeed, if all terms were exactly known, the energy imbalance should be zero, according to equation (6). At the 30 minute time-scale, the regression obtained for the grassland site is:

$$
H+L E+\mathrm{S}=0.87\left(R_{N E T}-G\right)+14.5 \quad\left(\mathrm{r}^{2}=0.92, \mathrm{n}=8062\right)
$$


1 Such a closure of the surface energy balance is well within the range of what is expected from

2 eddy covariance measurements (Foken 2008). The soil heat flux and its diurnal dynamics

3 proved to be extremely important, because the bare ground fraction is high at this site. In

4 August, the midday (11h-13h) average value of G is $172 \mathrm{~W} / \mathrm{m} 2$ at the grassland site, while the

5 grass cover is at its maximum. A comparison with soil heat flux measured with heat flux

6 plates at $5 \mathrm{~cm}$ in the soil shows that accounting for the heat stored in the soil between $-5 \mathrm{~cm}$

7 and the surface is critical. Using the flux plates and soil temperature at $-5 \mathrm{~cm}$ to estimate soil

8 heat storage provides a less satisfactory energy balance closure than $G$ estimated with the

9 harmonics method (not shown). In that respect, our results are in line with Heusinkveld et al.

10 (2004) and Jacob et al. (2008) and confirm the relevance of the harmonic computation for

11 semi-arid sites. The energy consumed by biochemical processes reaches 15 to $20 \mathrm{Wm}^{-2}$ at

12 midday and an August average of $3 \mathrm{Wm}^{-2}$. Figure 3a shows the energy balance closure

13 computed with day-time values (defined as data with $R_{N E T}>0$ ) expressed as $24 \mathrm{~h}$ averages,

14 which leads to the following relation:

$$
H_{d}+L E_{d}+S_{d}=0.78\left(R_{N E T d}-G_{d}\right)+12.8 \quad\left(\mathrm{r}^{2}=0.89, \mathrm{n}=150\right)
$$

16 where the subscript $d$ is for day-time average.

17 Such a relation is also commonly found with eddy covariance data in relatively favourable sites. In addition to the uncertainty affecting the ground heat flux, a lack of turbulent fluxes may come from large eddies and meso-scale circulations, which are not accounted for because the fluxes are calculated at the 30 minute time-scale (Finnigan et al. 2003, Foken 2008).

21 Discarding the data occurring during low turbulence periods, identified by friction velocity u* $22<0.15$, does not change this analysis and slightly improves the energy balance closure at 23 negative $R_{N E T}$.

24 When full 24-hour periods are considered, the imbalance averages to $-0.67 \mathrm{~W} \cdot \mathrm{m}-2$ (SD = 25 16.2) over the season. At this time scale, the soil heat flux is less critical, and both the heat 
1 flux plates and the harmonics methods give similarly small numbers, but the photosynthesis

2 energy becomes significant, since it is not balanced on a 24 hour basis during the growing

3 season. The imbalance is small and even slightly negative during the dry season (-5 W.m-2,

4 S.D.=14), implying that the sensible fluxes are accurately measured. During the rain season,

5 the imbalance is 9 W.m-2, (S.D. = 14.6), which provides an estimate of the error on the

6 turbulent fluxes. An order of 10 W.m-2 for the accuracy of 24 hour averaged fluxes can be

7 retained.

8 The forest site is a non-ideal site for eddy covariance measurements (Finnigan 2008, Foken

9 2008). Indeed, in sahelian landscapes, forested flooded sites rarely extend over large homogeneous areas, since they occur in valleys and low-lands only. The flux tower is located in the largest forest patch of the so-called AMMA super-site, which covers a $2 \mathrm{~km} \mathrm{x} 1.5 \mathrm{~km}$ area. The low-land is surrounded by drier ecosystems, and this favours advection and atmospheric circulations or large eddies, as will be implied by the examination of the seasonal cycle of the sensible and latent heat fluxes (see next section). In addition, the seasonal flood affects a fraction of the footprint, which varies with time. The flood also impacts soil heat flux measurement (heat storage in the water layer and energy inflow/outflow since water circulates) and therefore the energy balance closure in the foot-print.

At a 30 minute time-scale, the closure is

$$
H+L E+S=0.72\left(R_{N E T}-G\right)+22.0 \quad\left(\mathrm{r}^{2}=0.92, \mathrm{n}=8970\right)
$$

whereas daytime averaged energy balance closure (figure 3b) gives

$$
H_{\mathrm{d}}+L E_{d}+S_{d}=0.60\left(R_{N E T d}-G_{d}\right)+31.7 \quad\left(\mathrm{r}^{2}=0.72, \mathrm{n}=209\right)
$$

The energy balance closure is less good for the forest site than for the grassland site, although it is still in the range of commonly obtained values for non-ideal sites. Slopes of 0.72 for halfhourly data and 0.60 for day-time data indicate a lack of flux. The heat stored in the water during daytime is probably large during the flood, and may explain a significant part of the 
1 imbalance. The daytime-averaged value of $\mathrm{G}$ is $30 \mathrm{Wm}-2$ smaller during the flood than during

2 the periods before and after. Unfortunately, estimations of water volume in the footprint and

3 water temperature are not available to really quantify this storage term. The heat stored in the

4 biomass is not negligible at these time-scales, and biochemical storage has to be accounted

5 for, even at longer time-steps, since it does not equilibrate on a $24 \mathrm{~h}$ period.. Indeed, the $\mathrm{CO}_{2}$

6 flux measured over the forest reaches very high values, mostly due to the rapid growth of C4

7 grasses (Merbold et al. 2008), leading to an energy flux larger than $30 \mathrm{Wm}^{-2}$ at midday, with a

8 monthly-average value of $6 \mathrm{Wm}^{-2}$ in August.

9 At the 24 hour time-scale, the imbalance reaches $19.5 \mathrm{Wm}^{-2}$ on average over the measurement period, which corresponds to $14 \%$ of the net radiation. It has a clear seasonal cycle, with a maximum of $24.8 \mathrm{Wm}^{-2}$ (S.D. = 32) during the flood period, and a minimum of $-0.2 \mathrm{Wm}^{-2}$ (S.D. $=10.3$ ) during the dry period when the Harmattan wind is blowing (after DoY 300). These characteristics, together with the sensible and latent heat flux seasonality (see next section), suggest a significant advection term, corresponding to horizontal moisture gradient and transport, and possible atmospheric circulations. Indeed, the flooded forest constantly receives dry air from the surroundings, making horizontal advection a plausible candidate for the lack of flux of the energy balance. The typical error on the $H$ flux is most probably of the order of $10 \mathrm{Wm}^{-2}$ and the latent heat flux is thought to be underestimated during the wet season.

A comprehensive examination of the energy balance closure of the bare rocky soil and semidesert sites can not be performed. However, assuming that dry season evaporation is zero, the energy imbalance reduces to the residual of the radiation, sensible and ground heat flux. On a 2324 hour basis, the imbalance averages $-3.7 \mathrm{Wm}^{-2}($ S.D. $=10)$ at the bare rocky soil site. At the northern semi-desert site, the 24 hour average residual during the dry season (DoY < 165) has a mean of $-1.6 \mathrm{Wm}^{-2}$ (S.D. = 5.7), which can be attributed either to seasonal heat storage in 
1 the soil or a slight excess of energy. Nevertheless, these small numbers give reasonable 2 confidence in the flux calculations at this time scale.

\section{Seasonal cycle of sensible heat flux, latent heat flux and radiation balance}

The seasonal course of the daily sensible heat flux for the four sites is shown in figure 4, the net radiation and latent heat fluxes are shown in figure 5 and 6 . The different years have been superimposed to illustrate the seasonal cycle as completely as possible.

When averaged over $24 \mathrm{~h}$ for each day, the sensible heat flux at the semi-desert site is fairly constant over the summer (Fig. 4a). A similar flatness of the seasonal cycle is observed at the bare rocky soil site as well, with almost no difference between the dry period (e.g. May and June) and the monsoon period (August), except for a slight increase during the core of the monsoon (Fig. 4b). The seasonal cycle of $H$ is influenced by the cycle of the solar angle, which results in lower values of the incoming solar radiation around the winter solstice, as well as by an increase of the net long-wave radiation during the rainy season (Guichard et al. this issue). Low daily values occurring between day of year 150 and 250 correspond to rain events. By contrast, the seasonal cycle of the grassland site is more pronounced and it displays an opposite pattern, with $H$ decreasing during the monsoon season, from $70 \mathrm{~W} \cdot \mathrm{m}^{-2}$ in May to 20 W.m ${ }^{-2}$ in August and increasing back to the dry season value after DoY 260 (Fig. 4c). The forest site, (Fig.4d) exhibits the strongest contrast between the dry and wet season, with three well-marked periods. The sensible heat flux is strongest from April to June then the flux decreases during the early monsoon season. Last, a dramatic change occurs when the site is flooded, starting around day of year 220 in both 2006 and 2007. From this day onward, the sensible heat flux is close to zero, often with a downward flux after noon. This reflects the 
1 fact that most of the energy is being converted into the latent heat flux. It should be noted that

2 the flood season continues for a much longer period than the rainy season.

3

4 The magnitude of the sensible heat flux is primarily constrained by the availability of energy,

5 in the form of net radiation, and the partitioning of this energy into latent heat, sensible heat,

6 and the ground heat. The four sites noticeably differ in terms of $R_{N E T}$ (Fig. 5). Daily $R_{N E T}$

7 values corresponding to the days when sensible heat flux data are available at each site are

8 plotted with the same symbols as Fig. 4, whereas other available data are added to better

9 illustrate the seasonal course.

The seasonal cycle of net radiation is weak for the two bare soil sites (Fig. 5a and 5b). Much

12 lower values of $R_{N E T}$ at the northern semi-desert site result mainly from the large albedo, the sandy soil being brighter than the dark hard pan soil of Eguerit (bare rocky soil site). By comparison, the contrast between the dry and wet season net radiation is much higher at the grassland and forest sites (Fig.5c and 5d).

The four components of the radiation balance of the grassland and semi-desert sites are discussed in detail in Samain et al. 2008 and Guichard et al (this issue). Differences in net radiation during the dry season are primarily caused by soil type, ranging from bright sandy soils (semi-desert and grassland sites) to darker clay soil (forest) and even darker ferruginous hard pan outcrops (bare soil site). Plant material also plays a role during the dry season. For 21 instance, litter and standing straw have been shown to affect albedo values (Samain et al. 22 2008). In addition, the structure of the plant canopy in woodlands leads to the lowest albedo values, due to light absorption by stems and trunks. These factors explain the differences in 
$10.43,0.32,0.25$ and 0.17 for the semi-desert, grassland, bare rocky soil and forest sites

2 respectively.

3 Two main phenomena result in higher surface net radiation in the peak monsoon season at the

4 two vegetated sites. The first one is the growth of plants, triggered by the monsoon rainfall for

5 all grasses and forbs and for most of the trees (Fig. $7 \mathrm{a}$ and b). The expansion of the darker

6 plant leaves decreases albedo (Samain et al 2008) and reduces the long wave losses because

7 the plant canopies are cooler than bare soil during daytime. Leaf area index (LAI) of the

8 grassland and the open forest sites show similar seasonal evolution for the grass layer, but the

9 forest LAI reaches much higher values with both grasses and trees contributing almost equally to total LAI (Fig. 7b). The LAI cycle is longer at the forest site than at the grassland site, because the Acacia, and to a lesser extent, the grass layer, maintain green leaves over a longer period (Fig.7 b) since water is available for plants over a longer period. Plant growth therefore imposes a strong cycle on $R_{N E T}$ at both the grassland and forest site. By contrast, plant cover within the footprint of the flux station of the bare rocky soil and semi-desert sites is very low, with a LAI of 0.05 being measured at Eguerit on DoY 227 and an LAI of 0.01 at Bamba on DoY 233 of 2006.

17 The second factor leading to higher net radiation during the monsoon season is the availability of soil moisture, illustrated in figure 8 for the grassland and open woodland sites. At the grassland site, soil moisture in the root zone quickly responds to rain events. Since the soil is more than $90 \%$ sand, the amount of water retained in the surface layers is much lower than for the forest, where the soil is mostly clay. At the forest site, a drastic change of soil moisture occurs when the flood arrives, and saturated conditions are maintained over 2 to 3 months (Fig.8b). Moreover, open water is present above the soil during that period. Since water availability favours latent heat over sensible heat, it increases surface cooling and diminishes 
1 long wave losses, thus increasing net radiation. In addition to this direct effect, soil moisture

2 also enables plant growth, and indirectly increases $R_{N E T}$, as mentioned above.

3 By contrast, the rocky soil of Eguerit generates considerable runoff, precluding plant growth,

4 and the net radiation is controlled by the variations of down-welling shortwave and up5 welling and down-welling long wave fluxes. The sandy soil of the northern semi-desert site 6 generates limited runoff and retains some moisture (see de Rosnay et al, this issue), but in 7 rather small amounts and over short periods because rainfall averages $150 \mathrm{~mm}$ per year only, 8 which considerably hampers vegetation growth. As a result, the surface exerts only a weak 9 control on net radiation at the seasonal scale at the semi-desert site.

The seasonal increase in net radiation coincides with a marked decrease in sensible heat flux (Figures 4 and 5, vegetated sites). The main reason for this mismatch is that the factors driving the increase in $R_{N E T}$ also change considerably the surface flux partitioning towards increased latent heat flux at the expense of sensible heat flux. A clear illustration of this situation is revealed by the flooded forest site. As opposed to the seasonal cycle of $H$ (Fig. 4), $R_{N E T}$ is not much affected by the flood. Indeed, between DoY 150 and 220, daily $H$ decreases by $120 \mathrm{Wm}^{-2}$, whereas $R_{N E T}$ increases by circa $90 \mathrm{Wm}^{-2}$, with no obvious change in the seasonal cycle.

When the four different sites are compared, the differences in net radiation translate as differences in sensible heat in all seasons for bare soil sites (northern semi-desert and bare rocky soil) and in the dry season only for the vegetated sites (grassland and forest). Indeed, the diurnal cycle of $R_{N E T}$ and $H$ averaged over mid-May to mid-June (Fig. 9 a and b) are similar in terms of rank, with higher fluxes at the forest, then bare rocky soil, grassland and finally semi-desert sites. A fraction of $R_{N E T}$ is consumed by $L E$ at the grassland and forest sites, because of the first rains, which occurred in early June. As a result, the sensible heat 
1 flux of the grassland and semi-desert are very similar although the grassland net radiation is

2 slightly higher. Nevertheless, $R_{N E T}$ explains most of the inter-site differences at that time of

3 year. As a rule, in late winter and spring (dry season), daily $R_{N E T}$ and sensible heat flux

4 coincide.

5 A completely different situation prevails during the rain season (Fig. $9 \mathrm{c}$ and d) because the 6 two vegetated sites have the highest net radiation and the lowest sensible heat flux value. 7 Evapotranspiration (ETR) due to plant development and soil moisture availability is 8 responsible for such a seasonal shift in $H$. Latent heat fluxes for the northern semi-desert, the 9 bare soil, the grassland and the forest sites are shown in Figure 6. The daily latent heat fluxes differ among the four sites in terms of intensity, seasonality and day-to-day variability. The maximum daily rate is reached at the flooded forest, which maintains losses of the order of 6 $12 \mathrm{~mm} \mathrm{~d}^{-1}$ (or $175 \mathrm{Wm}^{-2}$ ) during the flood. The grassland evapotranspiration commonly reaches 3 to $4 \mathrm{~mm} \mathrm{~d}^{-1}$, whilst the northern semi-desert site occasionally reaches $3.5 \mathrm{~mm} \mathrm{~d}^{-1}$. Such differences reflect differences in available energy $\left(R_{N E T}\right.$ and $\left.H\right)$, since water is not limiting ETR just after a strong rain event. This is not the case for the bare rocky soil, where ETR never rises above $2.6 \mathrm{~mm} \mathrm{~d}^{-1}$ because the soil dries out rapidly (in a couple of hours) after a rain event and the soil superficial reservoir can not sustain high ETR rate during a full day. The seasonal cycle of ETR follows the rain cycle, except in the forest during the flood. Wetting and drying cycles are visible at each site except during the forest flood. Shorter cycles are found at the northern semi-desert site and the bare rocky soil site, whereas the vegetated sites show longer drying period and slower decrease of ETR, due to water extraction by the root systems (for instance before DoY 250 for the grassland site, or DoY 200 at the forest site).

The flooded open woodland is an extreme illustration of the physical preference in energy 
1 shows that the sensible heat flux is only slightly positive during the morning hours, and turns

2 negative in the late afternoon. The negative sensible heat flux in the afternoon implies that an oasis effect is at work, with dry and hot air flowing from the surrounding areas and heating

4 the surface.

Impact of surface hydrology on heat fluxes and energy balance

7

The landscape in the Gourma can be classified into three main types characterized by different local water balance and lateral water fluxes. As shown in figure 2, the first type consists of sandy soil including mobile and fixed dunes and sandy plains, where rainwater runs off the dune slopes into the inter-dune depression over a few tens to hundreds of meters, making this landscape type locally endorheic. The Agoufou grassland and Bamba semi-desert typify this type of landscape. The second type comprises rocky outcrops (sandstone, schists and ferruginous hard pans) locally coated with shallow loamy colluviums. Such a surface type converts most rainfall into surface runoff, which concentrates in gullies and is transported towards valleys and ponds. The Eguerit bare soil type is an example of this type of landscape. The third landscape type comprises gullies, loamy-clay valleys and depressions, and open water ponds. There, the water balance is fed by substantial surface run-on. Some of the loamy-clay depressions, such as the Kelma forest site, are flooded on a regular basis, depending on the intensity and distribution of rainfall events as well as on the size of the runoff area which feeds them. These depressions sustain the growth of acacia forest.

The local water balance has been computed by accumulating rainfall and evapotranspiration for the four sites (figure 10) along with net radiation converted to equivalent millimetres of evaporation. The two locally endorheic sites (grassland and semi-desert) display a similar behaviour, with accumulated rainfall being rapidly lost through the evapotranspiration 
1 process. Latent heat consumes a dominant fraction of the net radiation for the grassland but

2 not for the semi-desert site, since the total rainfall is much lower. ETR slightly exceeds

3 rainfall at the semi-desert site, as a result of the limitations of the residual method. For the

4 grassland site, $90 \%$ of the precipitation is rapidly returned to the atmosphere. By contrast, the

5 bare rocky soil site exhibits limited evaporation. The difference between rainfall and

6 evaporation indicates that run-off is the dominant loss of water, which can reach $70 \%$ of total

7 precipitation. Most of the net radiation is converted into sensible heat flux. Conversely,

8 accumulated evapotranspiration at the flooded forest site is more than twice as much as the

9 precipitation amount, indicating substantial run-on. Net radiation during the flood is entirely

10 converted into evapotranspiration, with even a possible slight under-estimation of the latent

11 heat flux as previously discussed.

12

13 As a result of the structure of the landscape, lateral water fluxes exert a strong control on the seasonal cycle of the heat fluxes and radiation balance in the Gourma. For instance, at the Eguerit bare soil site, the radiation balance and the partitioning between sensible and latent heat do not change much during the rainy season, since there is no vegetation development and a limited surface soil moisture reservoir. Conversely, locally endorheic sites receiving significant rainfall exhibit a significant seasonal cycle in soil moisture and plant growth, resulting in strong variations in net radiation, sensible and latent heat fluxes. 'Run-on' sites like the forested depression exhibit the strongest seasonal cycle in sensible heat flux, since run-on sustains above average plant growth and ample soil moisture availability. The control that lateral water redistribution exerts on surface fluxes is therefore dominant at the seasonal time-scale. There are also effects at shorter time-scales, typically of the order of a few days. In general, a rainfall event causes a sharp decrease in sensible heat flux, followed by a recovery 
1 shorter over the bare rocky soil of Eguerit, because little water is stored in the soil due to large

2 run-off. During the flood of the forest site, rainfall events have no effect on the heat fluxes, except through a drop of the incoming shortwave radiation during the event.

\section{Sensible heat fluxes at the landscape scale}

There is a strong interest in scaling the fluxes up to the scale of a grid-cell of atmospheric models, typically of the order of a few tens of kilometres. Up-scaling of fluxes however is a difficult exercise, as shown by Jarvis (1995). An attempt is made here to estimate the sensible heat flux at the scale of the AMMA northern supersite $(60 \mathrm{~km} \times 60 \mathrm{~km})$, following a simple aggregation scheme. The site has been classified from remote sensing data according to soil type, vegetation type and water regime (run-off prone units, locally endorheic units or run-on prone units), as detailed in Mougin et al., (this issue). Sensible heat fluxes from the three stations within the supersite are weighted by the relative area covered by each main land types (Figure 1 and Mougin et al., this issue), with the bare soil category being split into dark rocky soils (20\%) and bright loamy soils (15\%)

The spatially average flux $H_{a v e}$ is written as:

$$
H_{a v e}=\alpha \cdot H_{g}+\beta \cdot H_{b s_{-} d}+\gamma \cdot H_{b s \_b}+\delta . H_{f}
$$

where $H_{g}$ is the grassland sensible heat flux, $H_{b s \_d}$ is the measured dark rocky soil sensible heat flux, $H_{b s \_b}$ is the estimated bright bare soil sensible heat flux, and $H_{k}$ is the forest sensible heat flux. $\alpha, \beta, \gamma$ and $\delta$ are the relative areas covered by the four surface types (see table 2).

The $\mathrm{H}$ flux for bright bare soils is derived from the dark bare soil flux using a ratio of the $R_{N E T}$ of these two surface types under the assumption that the proportion of $H$ to $R_{N E T}$ is similar. According to measurements with two paired radiation stations in late 2008, $R_{N E T}$ over the 
$1 \quad H_{b s \_d}$. In addition to the baseline case, alternative formulations are used to bracket the

2 spatially-averaged $H$ flux. The bare soil surface is considered either as 'all dark' ( $\beta=0.35$ and

$3 \gamma=0$ in eq. 7) or 'all bright' $(\beta=0, \gamma=0.35)$, which are two extreme cases.

4 An additional weighting is designed to account for temporary flooded areas over clay soil,

5 which can cover $5 \%$ of the supersite area (Mougin et al. this issue, Gardelle et al., submitted).

6 This surface type, where flood is of short duration, is considered either as 'flooded forest' (in

7 the baseline case, $\alpha=0.55, \delta=0.10)$ or as 'grassland' $(\alpha=0.60, \delta=0.05)$.

8 For each 10-day period, the minimum and maximum of these 4 alternative weighting schemes

9 are retained and depicted as a shaded area on figure 11, with the objective of bracketing the supersite average flux, during the period when fluxes are available for the three surface types 11 (DoY 145 to 365, composite of all data over 2005-2007).

13 The up-scaled flux is found to closely follow the grassland time series, albeit showing slightly weaker seasonal dynamics. Figure 11 further establishes that the forest site, even if it shows a strong seasonal cycle, has a rather weak impact on the supersite scale sensible heat flux. The bare soil site dampens the seasonal cycle, without significantly affecting the average value, especially when the high albedo of the loamy soils is considered. The net effect of the bare soil and flooded site is to slightly moderate and delay the decline of the sensible heat during the monsoon. The grassland site is clearly close to the supersite average flux, the two other types of surface shaping the spatial variability within the supersite.

The deployment of the flux stations was purposely planned to sample the main surface types. However, a simple averaging of the fluxes from three stations is potentially affected by the small scale spatial heterogeneity of rainfall, which can change from one year to another, and therefore gaps in the sampling period. The inter-annual variability is extremely weak for the 
1 bare soil site, as judged by the comparison of the different years for sensible heat flux. At the

2 forest site, the inter-annual variability depends on both the date of arrival of the main rainfalls

3 and the duration of the flood, which occurred at similar dates in 2006 and 2007. Inter-annual

4 variability is more significant at the grassland site, in line with variations in LAI, soil

5 moisture and albedo. However, discarding one year or the other does not change the

6 aggregated flux significantly. Overall, this reinforces the conclusion that the super-site

7 average is close to the grassland flux and that the strong spatial variability is a robust feature,

8 because the seasonal cycle and the inter-site differences are much larger than the inter-annual

9 variability, at least for the measurement period. No scaling was attempted for the larger so-

10 called meso-scale AMMA site (3 degrees of latitude, 1 degree of longitude, figure 1), for

11 which the landscape types are similar and found in relatively similar fractions: $65 \%$ of sandy

12 soils, $18 \%$ of dark bare soils, $10 \%$ of bright loamy bare soils, $5 \%$ of bare clay soils, $2 \%$ of open water and flooded woodland. However at such a scale, it is not possible to assume that the precipitation pattern is less important than the surface type (vegetation, soil), even when longer time periods are considered. As an example, the grassland and semi-desert sites share the same soil properties but display completely different sensible flux, because of different precipitation leading to different soil wetness and vegetation type and growth.

\section{Discussion and conclusion}

The magnitude of the seasonal cycle of the sensible heat, latent heat, and net radiation fluxes measured above the Agoufou grassland in central Sahel can be compared to the data from the southern Sahel (SEBEX, Verhoef et al. 1999, HAPEX-Sahel, Gash et al. 1997, AMMA, Ramier et al. this issue). All these sites broadly share the same seasonal rhythm, with a short 
1 spring. The Agoufou grassland however displays a more pronounced peak of net radiation and

2 simultaneous decrease in sensible heat flux during the wet season. This is due to the

3 difference in latitude, which results in a shorter rainy season at $15.3^{\circ} \mathrm{N}$. Differences also arise

4 from, among other factors, the presence of bushes in the fallow sites near Niamey, which have

5 a longer leaf-out period than the annual grasses of the Agoufou grassland, where tree and

6 shrub cover is $2 \%$ only. Both factors influence the $R_{N E T}$ and $H$ seasonal variability. Such

7 differences are further illustrated when the grassland fluxes are compared to the data from a

8 site in Burkina-Faso at $11^{\circ} \mathrm{N}$ (Bagayoko et al. 2007), where crops are grown between ranks of

9 trees. The semi-desert, bare rocky soil and flooded forest sites are very different from what

10 has been measured so far in Africa, because of the scarcity of flux data in this continent.

11 The flux data collected over the three main landscape types provide a comprehensive but 12 contrasted view of the sensible heat flux and energy balance of this typical Sahelian landscape. Since such surface types form large landscape units, typically bands $15 \mathrm{~km}$ wide and $40 \mathrm{~km}$ long in the Gourma, such a contrast has the potential to create horizontal gradients of surface heat flux, which persist during the whole rainy season. In turn, these gradients may translate into differential boundary layer growth, meso-scale circulations and may even affect convection triggering and development. The flooded area has a more limited extension, covering approximately 5\% of the landscape, with an additional 5\% being flooded over much shorter periods, of the order of a few days. Its behaviour, in terms of flux partitioning, is singular, but because of the small spatial scales over which it occurs (typically of the order of

211 kilometre) it may have less impact on the atmospheric boundary layer.

22 The heterogeneity of the rainfall increases the heterogeneity of surface fluxes, which has been shown to impact convection and land-atmosphere interactions. Some of these effects have been established in the case of surface contrasts caused by soil moisture (e.g. Taylor et al. 2007). Here, we argue that for periods of a few days to a season, lateral water redistribution, 
1 soil type and vegetation patterns significantly shape the heterogeneity of the surface fluxes in

2 the central Sahel.

3 Site-level flux data are scarce in Africa, and have proved very useful to evaluate surface

4 models (Kahan et al. 2006, Clark et al. 2004, Cayrol et al. 2000, among others). Landscape-

5 scale variability has received less attention. The different landscape types that were

6 instrumented during the dry-down season in HAPEX-Sahel (bush fallow, millet crop and tiger

7 bush) produced much less spatial contrast (Gash et al. 1997) than found here. In the Gourma,

8 the fluxes over the bare soil area and the flooded forest are tightly controlled by surface water

9 redistribution, both directly through evapotranspiration and indirectly through vegetation

10 growth. The presence of negative sensible heat fluxes during the flood period points towards

11 lateral interactions between the landscape units mediated by atmospheric circulations. In that

12 respect, this Sahelian landscape mirrors the so called 'tiger bush' ("Brousse tigrée”), with

13 areas of bare soil generating runoff and areas collecting water as run-on allowing important

14 vegetation development. The spatial scale is much larger, by one order of magnitude, in the

15 case of the Gourma site, though.

16 In the future, this dataset will be used together with the data collected over the Niger and

17 Benin super-sites (Ramier et al. this issue, Guyot et al. this issue) to evaluate the ability of 18 land surface models to simulate the area-average and the landscape-scale heterogeneity of the 19 surface fluxes, starting with the AMMA Land Surface Models Intercomparison Project 20 (Boone et al., accepted), which inter-compares off-line simulation of surface fluxes, and the 21 AMMA Climate Models inter-comparison project (Hourdin et al. accepted), which evaluate 22 coupled surface/climate simulations of the African monsoon.

\section{Acknowledgements}


1 We thank Sarah Guibert for her help in classifying the SPOT images, Françoise Guichard for

2 stimulating discussion on the radiation components, and Hamma Maïga for his contributions

3 to the flux measurements as well as two anonymous reviewers. This research was funded by

4 the API-AMMA in the framework of the AMMA-CATCH ORE. Based on a French initiative,

5 AMMA was built by an international scientific group and is currently funded by a large

6 number of agencies, especially from France, UK, US and Africa. It has been the beneficiary

7 of a major financial contribution from the European Community's Sixth Framework Research

8 Programme and from the UK's National Environment research Council. Detailed information

9 in scientific coordination and funding is available on the AMMA International web site

10 http://www.amma- international.org. 


\section{References}

Allen S.J., J.H.C. Gash, M.V.K. Sivakumar, and J.S. Wallace, 1994, Measurements of albedo variation over natural vegetation in the Sahel, Int. J. Climatology, 14, 625:636

Avissar R., da Silva R.R, and Werth D., 2004, Implications of tropical deforestation for regional and global hydroclimate, in Ecosystem and Land Use Change, Geophysical Monograph Series, vol 153, 73-83

Bagayoko F., S. Yonkeu, J. Elbers, and N.V. de Giesen, 2007, Energy partitioning over the west Africa savanna: Multi-year evaporation and surface conductance measurements in Eastern Burkina Faso, J. Hydrol., 334(3-4), 545-559

Baldocchi, D.D., et al., 2001, FLUXNET: A new tool to study the temporal and spatial variability of ecosystem-scale carbon dioxide, water vapor, and energy flux densities, Bull. Am. Met. Soc., 82, 2415-2434.

Boone, A., P. de Rosnay, G. Balsamo, A. Beljaars, F. Chopin, B. Decharme, C. Delire, A. Ducharne, S. Gascoin, F. Guichard, Y. Gusev, P. Harris, L. Jarlan, L. Kergoat, E. Mougin, O. Nasonova, A. Norgaard, T. Orgeval, C. Ottlé, I. Poccard-Leclercq, J. Polcher, I. Sandholt, S. Saux-Picart, C. Taylor, Y. Xue, 2008: The AMMA Land Surface Model Intercomparison Project (ALMIP), submitted to Bull. Atmos. Meteor. Soc.

Cayrol P., L. Kergoat, S. Moulin, G. Dedieu, and A. Chehbouni, 2000, Calibrating a coupled SVAT-vegetation growth model with remotely sensed reflectance and surface temperature A case study for the HAPEX-Sahel grassland sites, J. App. Meteorol., 39(12), 2452-2472

Charney J., P.H. Stone and W.J. Quirk 1975, Drought in the Sahara: A biogeophysical feedback mechanism, Science, 187, 4175, 434-435.

Clark D.B., C.M. Taylor, and A.J. Thorpe, 2004, Feedback between the land surface and rainfall at convective length scales, J. Hydrometeorol., 5(4), 625-639

de Rosnay, P., A. Boone, A. Beljaars, and J. Polcher, 2006, AMMA Land-Surface modeling and intercomparison projects. GEWEX News, February, 16 (1), 10-11

de Rosnay, P., C. Gruhier, F. Timouk, F. Baup, E. Mougin, P. Hiernaux, L. Kergoat, and V. Le Dantec, Multi-scale soil moisture measurements over the Gourma meso-scale site in Mali, this issue, submitted.

Finnigan J., 2008, An introduction to flux measurements in difficult conditions, Ecological Applications, 18(6), 1340-1350

Finnigan J.J., R. Clement, Y. Malhi, R. Leuning, and H. A Cleugh. 2003. A re-evaluation of long-term flux measurement techniques. Part 1: averaging and coordinate rotation. BoundaryLayer Meteorology 107:1-48.

Foken T., 2008, The energy balance closure problem: An overview, Ecological Applications, 18(6), 1351-1376 
2 Frappart F., P., Hiernaux, F. Guichard, E. Mougin, L., Kergoat, M. Arjounin, F. Lavenu, M. 3 Koité, J.-E. Paturel, and T. Lebel, Rainfall regime over the Sahelian gradient in the Gourma, 4 Mali, this issue, submitted.

5

Gardelle J., Hiernaux P., Kergoat L., and Grippa M., Evidence of an increase in pond surface during the multi-decenal drought in pastoral Sahel, HESS, submitted

Gash J.H.C. et al., 1997, The variability of evaporation during HAPEX-Sahel intensive observation period, Journal of Hydrology, 385-399.

Giannini A., R. Saravan and P. Chang, 2003, Oceanic forcings of Sahel rainfall on interannual to interdecadal time scales, Science, 302, 1027-1030.

Guichard F., L. Kergoat, E. Mougin, F. Timouk, F. Baup, P. Hiernaux and F. Lavenu, Surface thermodynamics and radiative budget in the Sahelian Gourma: seasonal and diurnal cycles, this issue, accepted.

Guyot A., J.-M. Cohard, S. Galle. and S. Anquetin, 2008. Estimating latent heat flux at catchment scale using a with large aperture scintillometer combined with soil measurements. This issue, submitted

Heusinkveld B.G., A.F.G. Jacobs, A.A.M. Holtslag, and S.M. Berkowicz, 2004. Surface energy balance closure in an arid region: role of soil heat flux. Agricultural and Forest Meteorology, 122(1-2), 21-37.

Hiernaux P., E. Mougin, L. Diarra, N. Soumaguel, F. Lavenu, Y. Tracol, and M. Diarra, Sahelian rangeland response to changes in rainfall over two decades in the Gourma region, Mali, this issue, submitted.

Hillel D., 1998. Environmental Soil Physics. Academic Press, 771 pp.

Hourdin, F., I. Musat, F. Guichard, F. Favot, P. Marquet, A. Boone, J.-P. Lafore, J.-L. Redelsperger, P. Ruti, A. Dell'Aquila, T. Losada Doval, A. Khadre Traore, H. Gallee, 2008, AMMA-Model Intercomparison Project, submitted to Bull. Amer. Meteor. Soc.

Jacob A.F.G., B.G. Heusinkveld, and A.A.M. Holtslag, 2008, Towards closing the surface energy budget of a mid-latitude grassland, Boundary-Mayrer Meteorol., 126, 125-136. doi 10.1007/s10546-007-9209-2

Jarvis, P.G., 1995, Scaling processes and problems. Plant, Cell and Environment, 18(10), 1079-1089

Kahan D.S., Y. Xue, and S.J. Allen, 2006, The impact of vegetation and soil parameters in simulations of energy and water balance in the semi-arid sahel: A case study using the SEBEX and HAPEX-Sahel data, J. Hydrol., 320, 238-259

LeMone M.A., F. Chen, J.G. ALfieri, M. Tewari, B. Geerts, Q. Miao, R.L. grossman and R.L. Coulter, 2007, Influence of land cover and soil moisture on the horizontal distribution of 
sensible and latent heat fluxes in Southeast Kansas during IHOP_2002 and CASES-97, J. Hydromet., 8, 68-87

Liebethal C., and T. and Foken, 2007. Evaluation of six parameterization approaches for the ground heat flux. Theoretical and Applied Climatology, 88(1), 43-56.

Merbold et al., 2008, Precipitation as driver of carbon fluxes in 11 African ecosystems, Biogeosciences Discuss. 5, 4071-4105

Mohr K.I., R.D. Baker, W.-K. Tao, and J.S. Famiglietti, 2003, The sensitivity of West African convective line water budgets to land cover, J. Hydrometeorol., 4(1), 62-76

Mougin et al., The AMMA-CATCH Gourma observatory site in Mali: Relating climatic variations to changes in vegetation, surface hydrology, fluxes and natural resources, this issue accepted

Nicholson S.E., 2000, Land surface processes and Sahel climate. Rev. Geophs., 38, 117-139.

Nicholson S.E., C.J. Tucker and M.B. Ba, 1998, Desertification, drought, and surface vegetation: An example from the West African Sahel, Bull. Am. Meteor. Soc., 79, 815-829.

Oncley S.P., et al., 2007, The Energy Balance Experiment EBEX-2000, Part I: Overview and energy balance, Boundary-Layer Meteorology, 123, 1-28. doi 10.1007/s10546-007-9161-1

Ramier D., N. Boulain, B. Capppelaere, F. Timouk, M. Rabanit, C.R. Lloyd, S. Boubkraoui, F. Métayer, L. Descroix, V. Wawrzyniak, Towards an understanding of coupled physical and biological processes in the cultivated Sahel -1 . Energy and water, this issue, accepted.

Samain O., L. Kergoat, P. Hiernaux, F. Guichard, E. Mougin, F. Timouk, and F. Lavenu, 2008, Analysis of the in-situ and MODIS albedo variability at multiple time scales in the Sahel. J. Geophys. Res., 113, D14119, doi 10.1029/2007JD009174

Schotanus P., F.T.M. Nieuwstadt, and H.A.R. DeBruin, 1983, Temperature measurement with a sonic anemometer and its application to heat and moisture fluctuations. Bound.-Layer Meteor., 26, 81-93

Taylor C.M., E.F. Lambin, and N. Stephenne, 2002, The influence of land use change on climate in the Sahel, J. Climate, 15(24), 3615-3629

Taylor C.M., D.J. Parker, and P.P. Harris, 2007, An observational case study of mesoscale circulations induced by soil moisture, Geophys. Res. Lett., 34(15), L15801

Van Wijk W., and De Vries, D., 1963. Periodic temperature variations in a homogeneous soil, Physics of Plant Environment, 103-143.

Verhoef A., S.J. Allen, and C.R. Lloyd, 1999, Seasonal variation of surface energy balance over two Sahelian surfaces, Int. J. Climatology, 19(11), 1267-1277 
1 Verhoef, A., B.J.J.M. van den Hurk., A.F.G. Jacobs, and Heusinkveld B.G., 1996. Thermal 2 soil properties for vineyard (EFEDA-I) and savanna (HAPEX-Sahel) sites. Agricultural and 3 Forest Meteorology, 78(1-2), 1-18.

4

5 Zeng N., J.D. Neeling, K.M. Lau and C.J. Tucker, 1999, Enhancement of Interdecadal 6 Climate Variability in the Sahel by Vegetation Interaction,Science, 286, 5444, 1537 - 1540. 
Figure 1

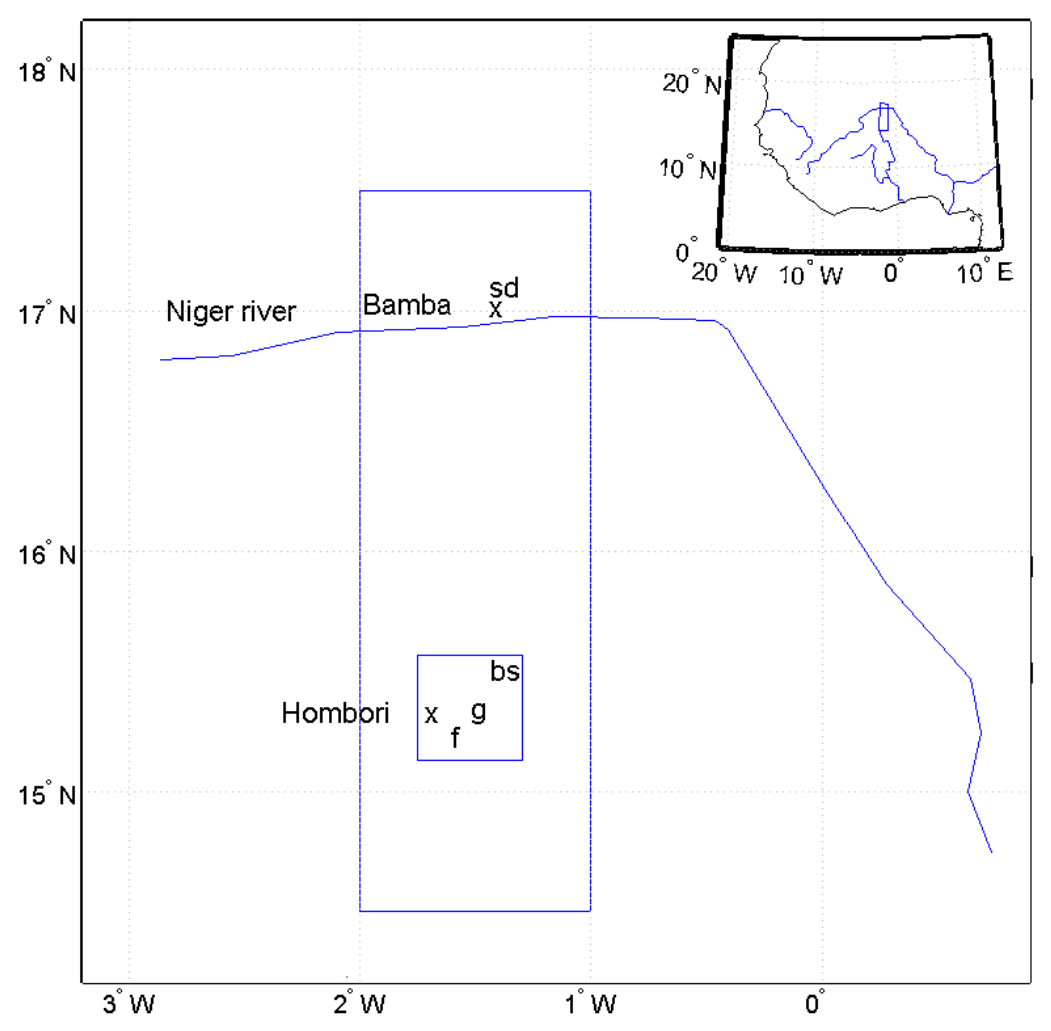

Figure 1. Map of the meso-scale Gourma site, with the four eddy covariance sites. The semidesert site (sd) is north of the Niger river, whereas the three others, grassland (g), bare rocky soil (bs) and forest (f), are located in the so-called super-site. (x) are for the villages of Hombori and Bamba. 


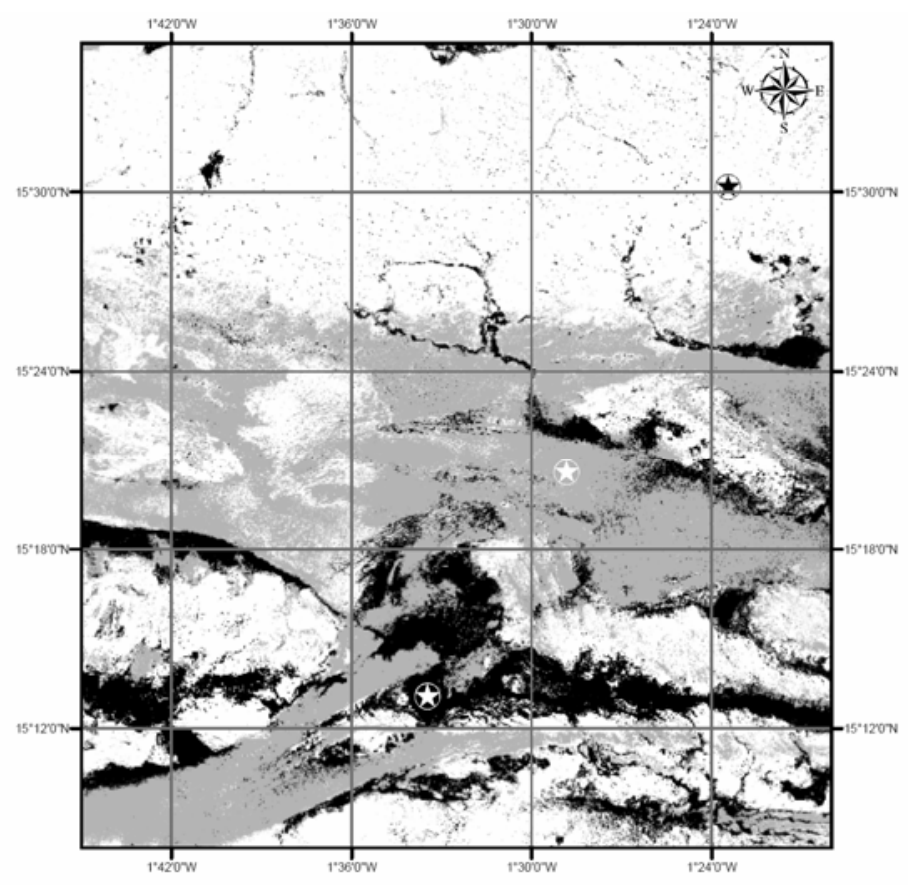

Figure 2. Map of the main soil types over the Hombori AMMA super-site. In grey, sandy soils, which are locally endorheic. In white, sandstone and hard pan outcrops, exporting surface run off. In black, loamy-clay soils receiving run-on, which includes ponds and flooded acacia woodland. Stars indicate the three flux stations. 

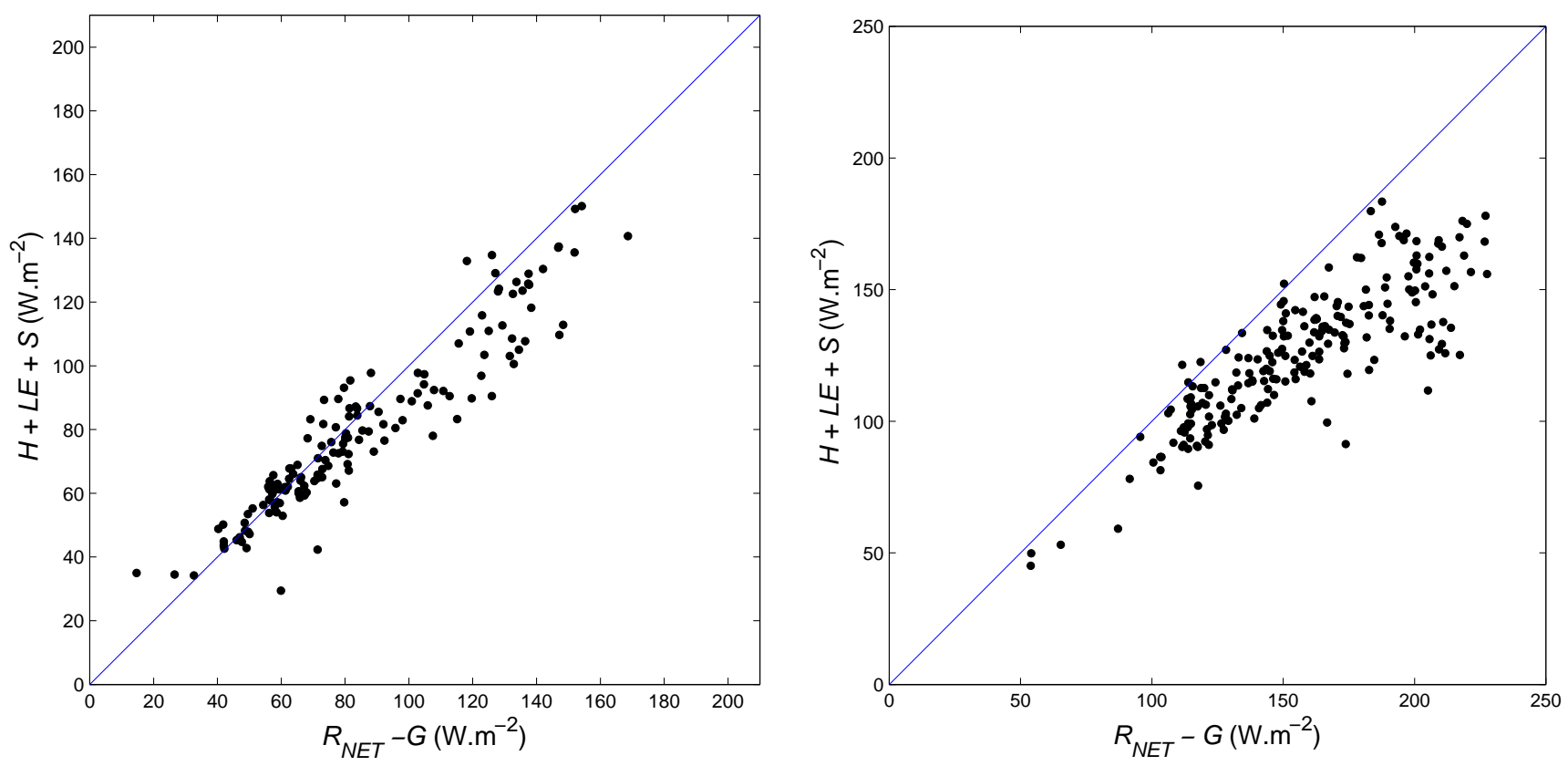

Figure 3 a): Daily daytime-average of the sum of latent, sensible, and storage heat fluxes versus net radiation minus ground heat flux for the grassland site. b) Same as a) but for the forest site. 

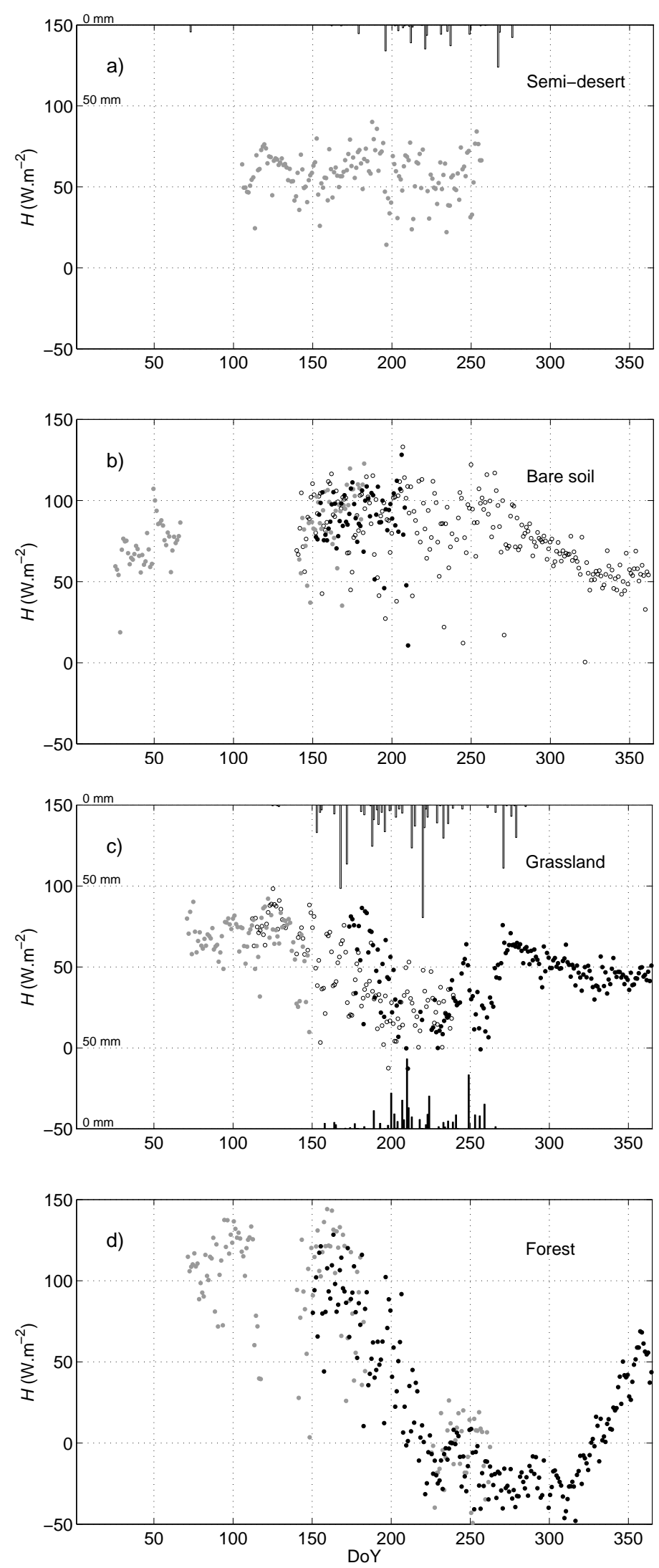

Figure 4: 24h-average sensible heat flux over the four sites. Open symbols are for 2005, grey for 2006, black for 2007 and early 2008. 2006 rainfall is shown for semi-desert, 2005 and 2007 rainfall are shown for the grassland (top and bottom of panel c). 
1 Figure 5
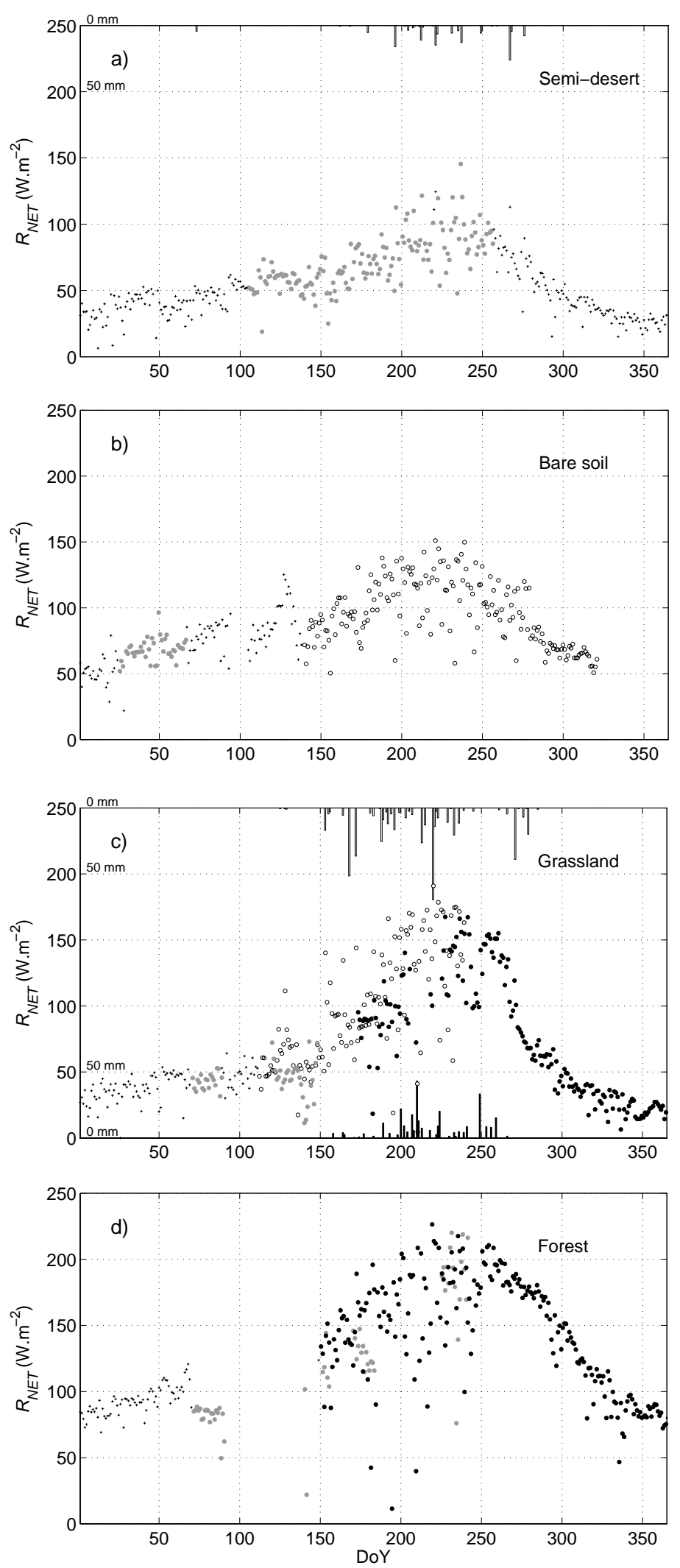

Figure 5: Same as Fig. 4 but for 24h-average net radiation. (+) correspond to days when no sensible heat data are available. 
Figure 6
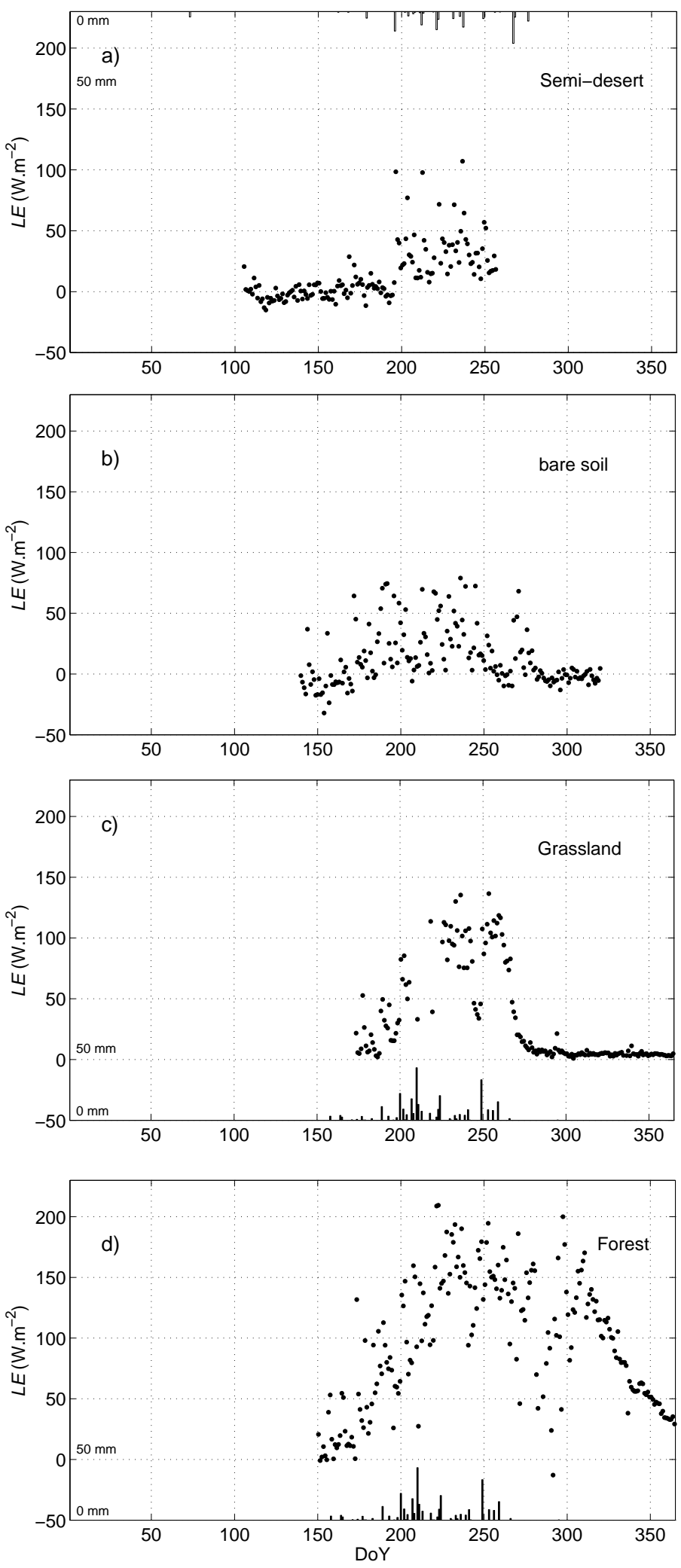

Figure 6: 24h-average latent heat flux calculated by residual method (semi-desert (a) and bare rocky soil sites (b)) or measured by eddy-covariance (grassland (c) and forest (d)). 

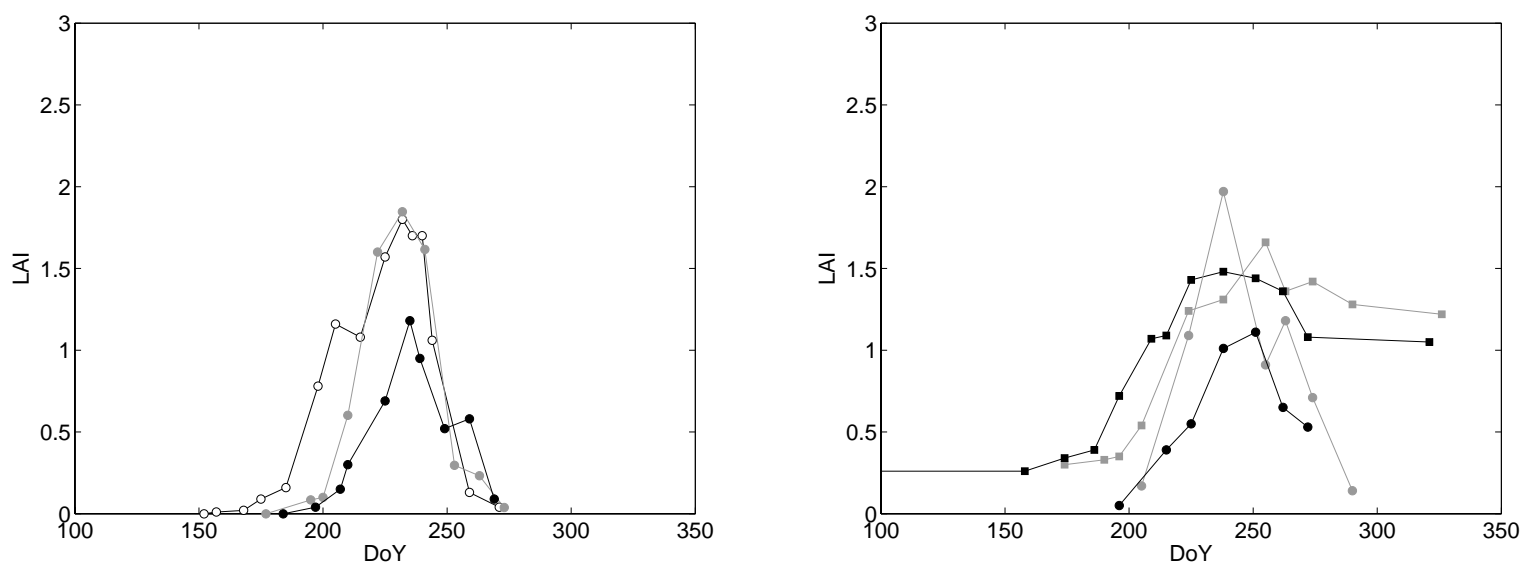

Figure 7 a) Time series of Leaf Area Index for the grassland site in 2005 (open symbol), 2006 (grey) and 2007 (black).

b) Time series of Leaf Area Index for the grass (circle) and Plant Area Index for the tree (square) at the forest site in 2006 (grey) and 2007 (black). 
1 Figure 8
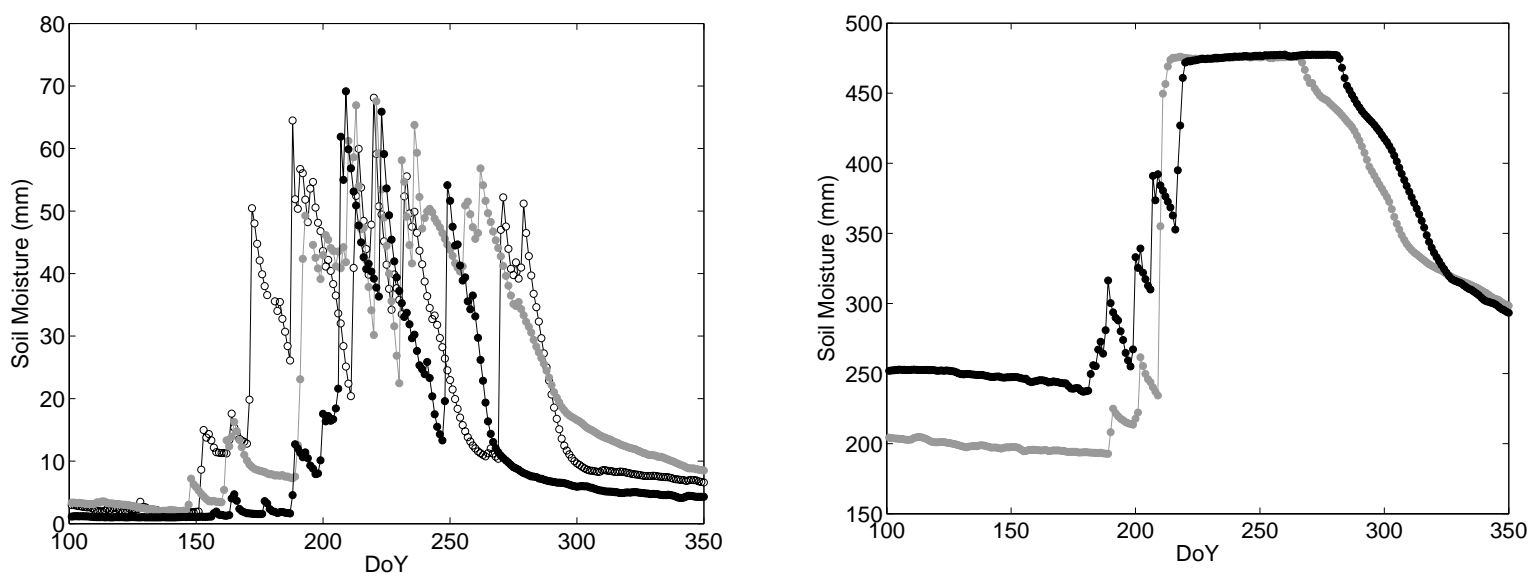

Figure 8 a) Time series of soil moisture content integrated over $1 \mathrm{~m}$ for the grassland site (sandy soil). Open symbols are for 2005, grey for 2006 and black for 2007.

b) Same as a) but for the flooded forest site (loamy-clay soil). Grey symbols are for 2006 and black for 2007. 
Figure 9
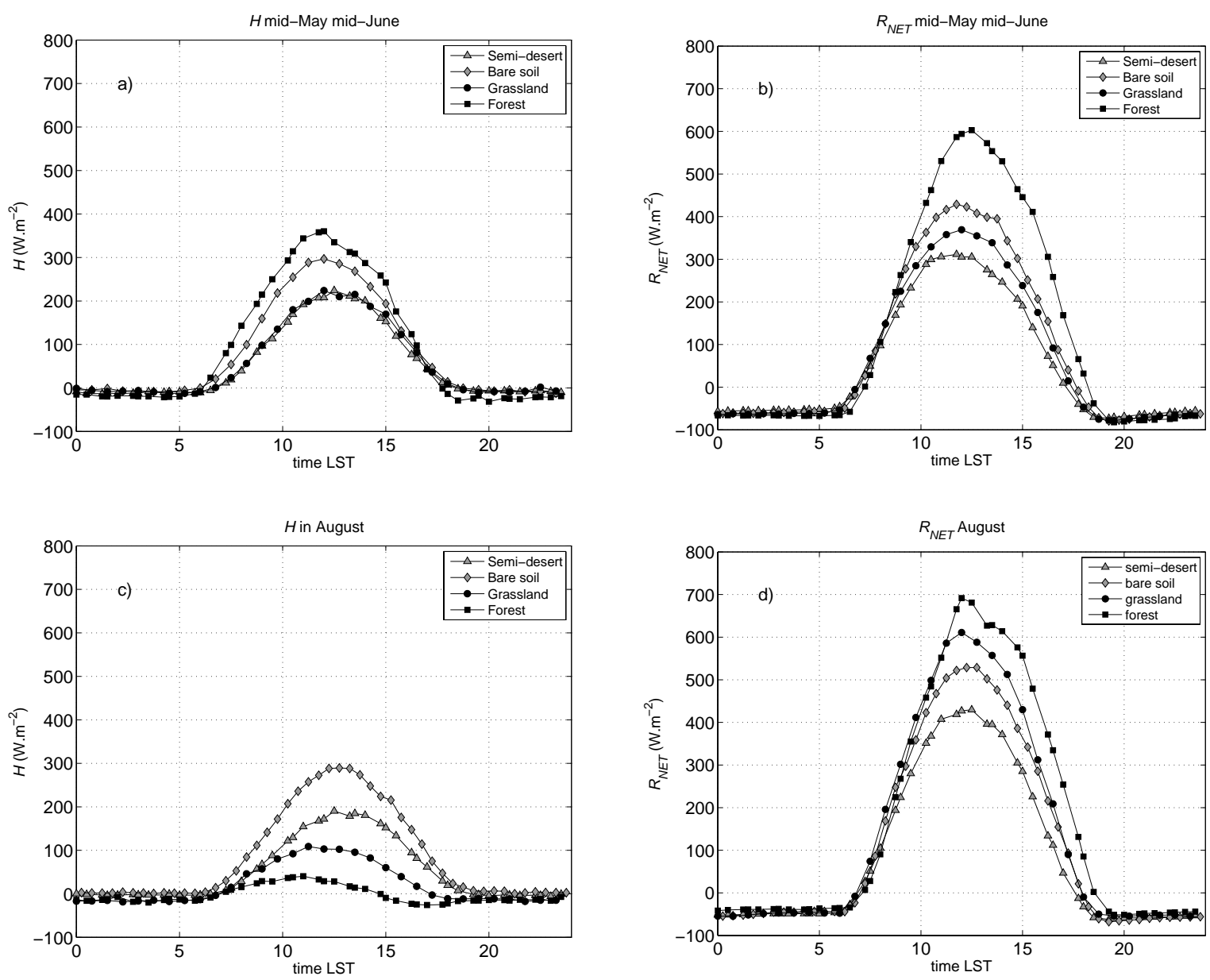

Figure 9 a) Diurnal cycle of $H$ averaged over mid-May to mid-June. b) same as a), but for net radiation, c) same as a but for August, d) same as b) but for August. 
Figure 10
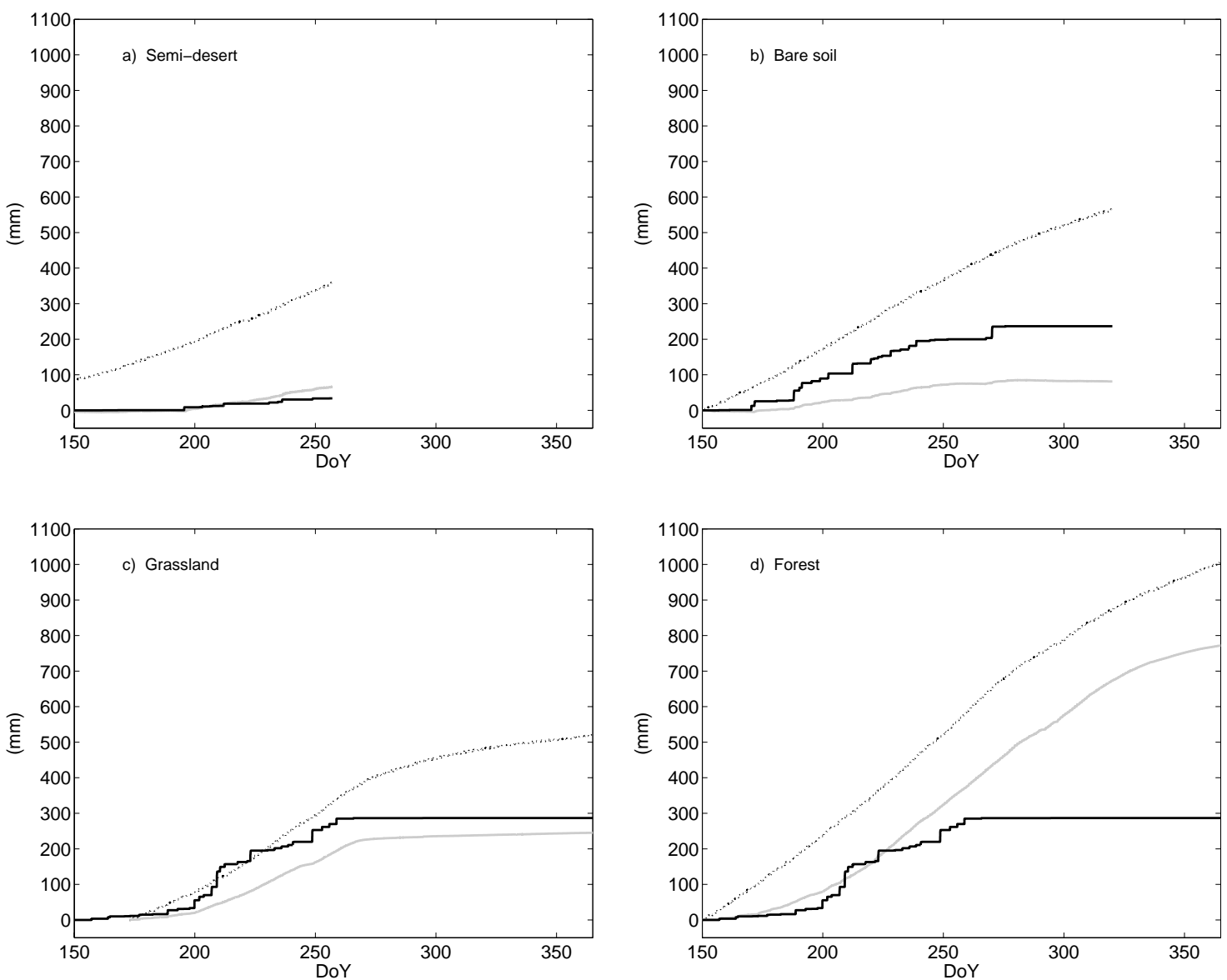

Figure 10: Accumulated net radiation (dotted line), rainfall (black) and latent heat flux (grey) for the semi-desert site in 2006 (a), the bare rocky soil in 2005 (b), the grassland (c) and forest (d) in 2007. 


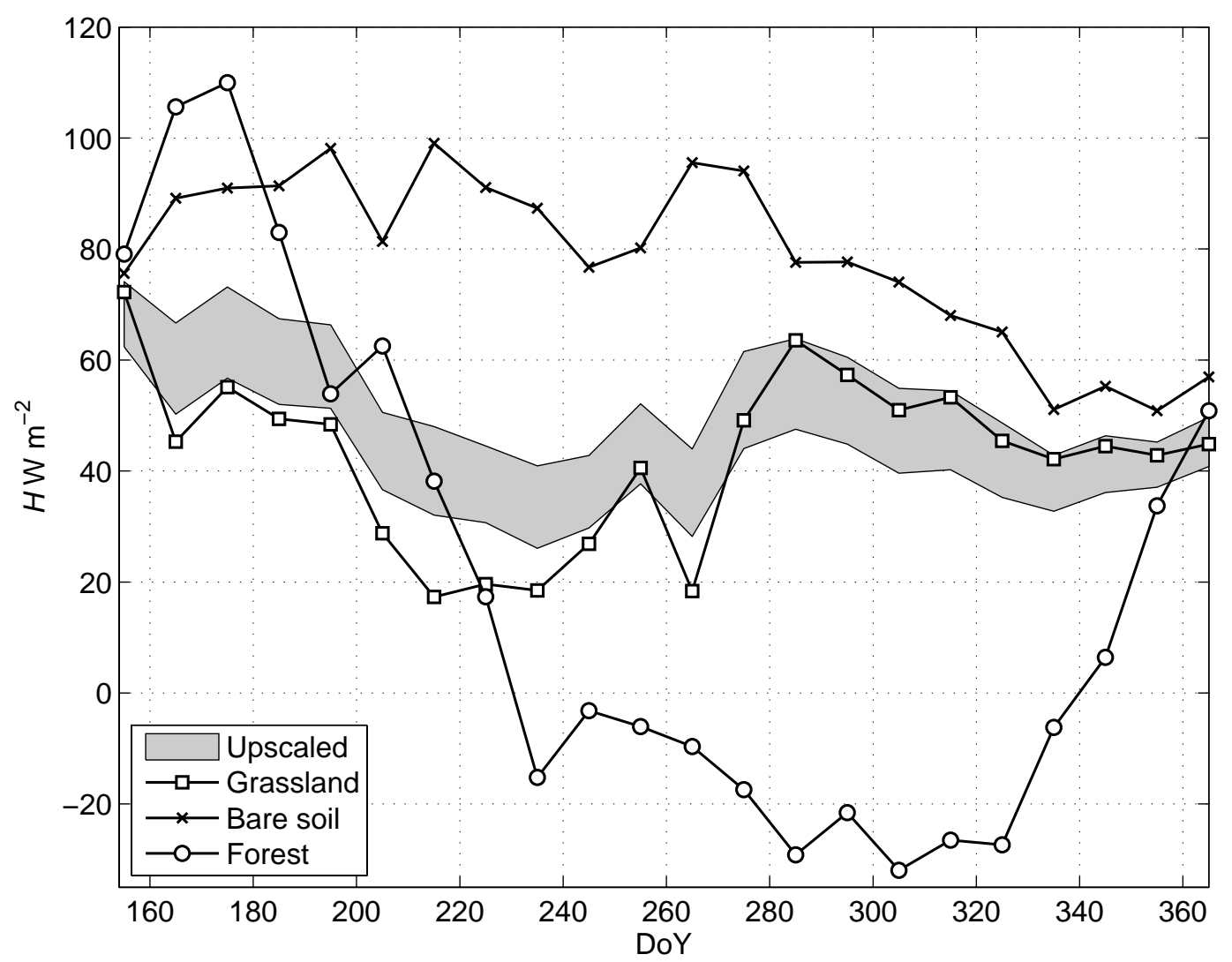

Figure 11: Sensible heat flux scaled up to the super-site scale (shaded area) along with sensible heat flux from the three flux stations of the super-site using all data over the 2005-2007 period. 
1 Table 1

\begin{tabular}{|c|c|c|c|c|}
\hline Site & Sensor & $\begin{array}{l}\text { Measurement height } \\
\text { (m) }\end{array}$ & $\begin{array}{l}\text { cover } \\
(\%)\end{array}$ & $\begin{array}{l}\text { Vegetation height } \\
\text { (m) }\end{array}$ \\
\hline Semi-desert & Solent R3 Gill & 2.5 & Grass 1\% & 0.2 \\
\hline Bare soil & Solent R3 Gill & 2.5 & - & - \\
\hline \multirow[t]{5}{*}{ Grassland } & Solent R3 Gill & 3.5 & Grass 1-70\% & 0.01 to 0.3 \\
\hline & $(2005-2006)$ & & Tree $2 \%$, & 1.5 to 2.5 \\
\hline & CSAT3 & & & \\
\hline & Campbell & & & \\
\hline & $(2007-02 / 2008)$ & & & \\
\hline \multirow[t]{5}{*}{ Forest } & Solent R3 Gill & 13 & Tree $45 \%$, & 8 \\
\hline & $(2005-2006)$ & & Grass 1-90\% & \\
\hline & CSAT3 & & & \\
\hline & Campbell & & & \\
\hline & $(2007-02 / 2008)$ & & & \\
\hline
\end{tabular}

2

3 Table 1: Eddy-covariance site characteristics.

4

5 
2 Table 2

3

\begin{tabular}{lcccc} 
& $\alpha$ & $\beta$ & $\gamma$ & $\delta$ \\
\hline Baseline case & 0.55 & 0.20 & 0.15 & 0.10 \\
\hline Dark case & 0.55 & 0.35 & 0. & 0.10 \\
Bright case & 0.55 & 0 & 0.35 & 0.10 \\
Grass case & 0.60 & 0.20 & 0.15 & 0.05
\end{tabular}

4

5

6 Table 2. Values of the parameters used in the 4 scenarios to scale the sensible heat flux up to 7 the super-site scale.

8 